\title{
Junior High School Students' Writing Mastery on English Decriptive and Recount Texts
}

\author{
1Febri Rama Suci, ${ }^{2}$ Maratus Shalihah, ${ }^{* 3}$ Darmayenti \\ 1, 2, 3UIN Imam Bonjol Padang, Indonesia \\ *Correspondence address Email: darmayenti@uinib.ac.id \\ Email: ${ }^{1}$ febriramasuci94@yahoo.com; Email: ${ }^{2}$ mrtsshalihah@yahoo.com
}

DOI: $\underline{\text { https://doi.org/10.15548/turast.v7i1.764 }}$

(Diterima: 14 Maret 2019. Disetujui: 24 Juni 2019. Diterbitkan: 30 Juni 2019)

\begin{abstract}
Abstrct
This paper aimed at finding out and described deeply the students' writing skill and their mastery on descriptive and recount texts at class VIII of Junior High School 2 Sintoga. This was a descriptive research type and 22 students were respondents of the research. Writing tests on descriptive and recount texts were used to collect the data. Jacob's theory and Sudijono's were used to analyze the data. It was found that the students got fair skill for both mean score of students based on component writing descriptive and recount texts. For the each component of genres, they got lower score on content, organization of text, vocabulary, and language use. The students made the mistakes in orientation and events and did not give the information and the reason clearly in the orientation, and wrote their experience un chronologically in events. It is concluded that the students' writing skill should be improved. It implies that English teacher should be able to find out effective techniques and strategies in building students' writing motivation in writing.
\end{abstract}

Keywords: Writing mastery, descriptive text, recount text

\section{INTRODUCTION}

Writing is one of skill should be learned and mastered by any level of students in learning English. The purpose of teaching writing in Junior High School level are the students know how to write paragraph and learn how to write in various genre using different register.

Genre is to represent the norm of different kind of writing (Harmer: 2004).
In addition, genre is a type of text in which of text has communicative purposive, generic structure, and language feature (Harmer, 2008). Two of some genres should be mastered by the students in learning English writing. Those are Descriptive Text and Recount Text.

Descriptive text is the description of person, place, and things. Oshima and Hogue (1998) explain that descriptive 
text has to be in chronological order as a way to organize a composition. The purpose of descriptive text is to describe a particular person, animal, place or thing. Descriptive of person is an impression, or a character sketch, appearance, and character personality. Descriptive of animal is the text to describe animal mentioned name, habitation, and appearances and the behavior. Descriptive of place is by mentioning name of the location, and the characteristic of it is surrounding. Descriptive of thing write a description about something.

In writing descriptive text, students should be able to write the generic structures and use of language features appropriately. According to Hammond in Mursyid (2006) that generic structures of descriptive text consist of identification and description. Identification identifies the phenomenon to be described. Description describes parts, qualities, characteristics, etc. The language features of the text focuse on specific participants, use of simple present verbs of being and having, descriptive adjectives, detailed noun phrase, action verb, adverbials and figurative language.

Recount is to reconstruct past experiences by retelling events in original sequence (Hyland, 2003). It is the text to retell past event or to retell that something happened. Through recount text, the students are expected to get information from a text, to identify main ideas in a text and identify parts of a recount text.

Moreover a recount text consists of generic structure and lexicogrammatical features. Generic structures of recount text are orientation (background information about who, where, and when), sequences of events (tell what happened in the past) and re-orientation (it is optional-closure of events).

Besides, a recount text also has lexicogrammatical features such as focus on specific participants, use of material processes, circumstances of time and place, use of past tenses, and focus on temporal sequences, use of conjunctions.

In order to find out the students' skill on writing, the teacher should assess them through writing test and analyze the result of students' paper by coding. Wiggle (2002) says that writing is a skill in language learning and all teachers need to evaluate their students' writing ability. It can be said that assessment is important for writing. Teachers can assess how the students' competency in writing. In order of considering the students' writing, Brown (2004) stated that coding is one a symbol for correcting.

Coding is the process of giving codes to each parts of students' written work those are related to word order, spelling, verb tense, or spelling. And based on Oshima (2006) there are editing symbol to correct writing test. Assessment of writing descriptive text is to know and to identify the students' generic structure mastery and also to help plan future instruction. Assessment provides teacher to know which skill levels that the students' have. It is needed to help the teacher to know level of students writing skill on descriptive text and recount texts. 
The preliminary study at State Junior High School 2 Sintoga proved that descriptive and recount texts had been taught at class VIII of by the teachers, but they had not analyzed the students' mastery on generic structure of genre yet. The teachers just focused on evaluation generally without analyzing students' writing based on components of writing and generic structure of genres. The previous researches have proved that students face difficulty in on genres (Nugraha, 2012). Some of the students got problems on grammar (Istibsyaroh, 2014 Erma,2008).

Concerning with those facts, this paper aims at describing the students' mastery on generic structure of descriptive and recount texts at two Junior High Schools in West Sumatera. It implies that the result of the research can inform the teachers about the students' writing mastery on English writing comprehensively.

\section{METHOD}

This was a descriptive research type. It is to identify the students' mastery on English writing descriptive and recount texts. Gay ((2000) states that descriptive research determines and describes the way things are. 22 students of class VIII of State Junior High 2 Sintoga in academic year 2017/2018, selected randomly, as the respondents of this study.

Writing test was used to collect the data. The writing test distributed to students which have been taken as the respondents of this research. One of Eight topics was chosen by the students for the writing test. Then, the researcher asked them to write descriptive and recount texts based on the topic selected. The result of the test was classified into excellent, good, fair, poor and very poor by using Jacob' rubric (1981). The percentage of students' skill in writing descriptive and recount text used formula Sudijono (2006). Quantitative Measurement by counting the total score, frequency or percentage the teachers' reinforcement was used to analyze the data. SPSS program to calculate mean and standard of deviation of tests was also used to analyze the data.

\section{RESULT AND DISCUSSION}

Based on the result of the students' writing test, it was found the students' writing skill on descriptive and recount texts. First, the students' generic structure mastery on descriptive text found that there were five writing components, namely content, organization, vocabulary, language use and mechanic.

\section{Students' Mastery on Descriptive}

The result of data analysis of the students' papers showed that the mean of the writing test on descriptive test is 58.1. It means that the mean of students' score are below the Minimum Achievement Criteria for English lesson that is 75 point. The students' scores on content of writing are $(61 \%)$. It is categorized into fair score. The average students' score organization is fair. The score are $(66 \%)$. The result of the students score in writing generic 
structure skill is in fair category, it is $(57 \%)$. Vocabulary indicator shows fair. The score is $49 \%$. The fourth indicator is language use, the students' skill in this indicator was poor (49\%). The fifth indicator is mechanics, the students skill in this indicator is poor $(45 \%)$. It indicates that the students' skill in language use is in poor category.

Based on the data interview, most of the students state that the students do not understand in organizing the text, choosing of appropriate words, having lack of vocabulary, mechanics, such as coma, full stop, and capitalization in a wrong place. It can be seen on the following graphics.

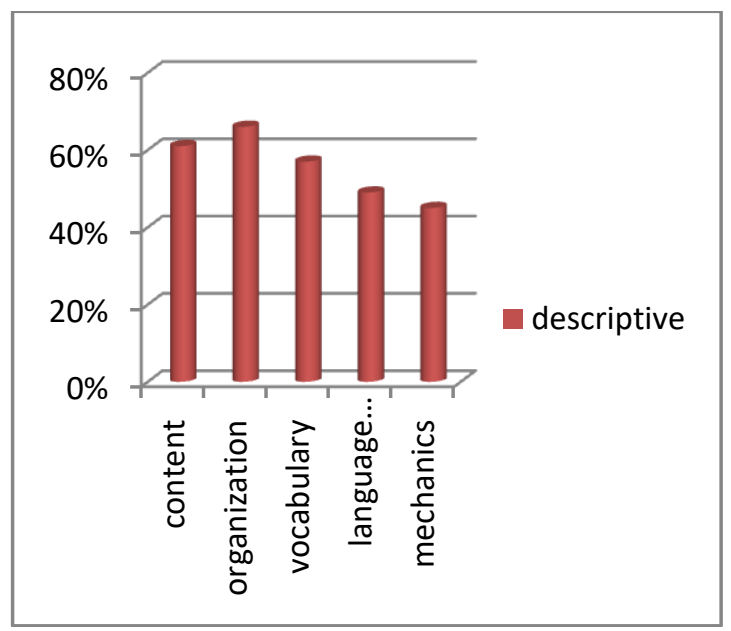

Graphic 1: Student's Skill Mastery on Components of Writing on Descriptive Text

The students' ability in developing stage of writing is also low. There are four stages are conducted by the students, namely, beginning stage, developing stage, consolidating stage and extending stage. There are 14 students $(77.14 \%)$ able to create the paragraph in beginning stage, and 8 students $(22.85 \%)$ on developing stage. The graphic below shows the student stage in writing descriptive and recount texts.

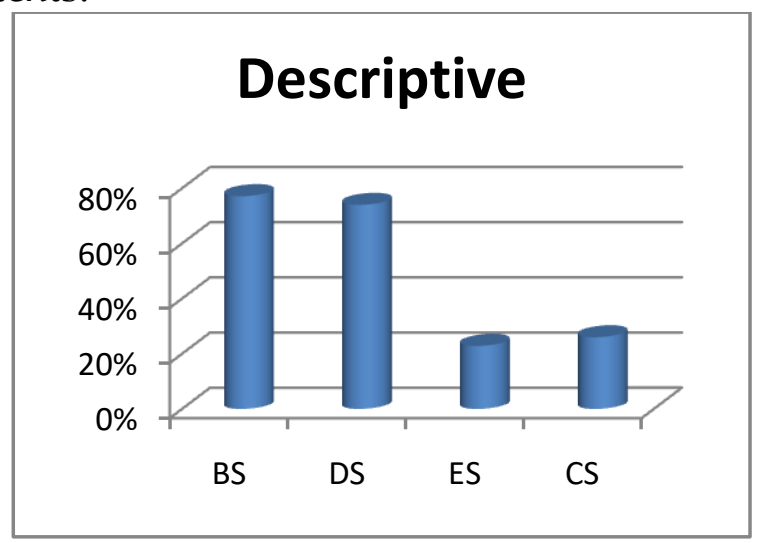

Graphic 2: Student's Stage in writing Descriptive Text

The graphic above shows that the percentage of the stage at class VIII that related beginning stage, developing stage, consolidating stage and extending stage. The main focused of the beginning stage and developing stage is to help the students to understand the purpose, organization, structure and language feature of the texts descriptive and recount.

Someone can be said that she or he can mastered the generic structure in writing descriptive text if in identification identifies the described phenomenon (Dadi, 2015). It consists of topic about what is going to be described visually or mentally. Identification consists of one or more sentences, or one short paragraph, (Pardiyono, 2013). And the characteristic of identification are; contain of the topic and "who" or "what" question. In description, description describes parts, qualities, and characteristics (Dadi, 2015). Description contains an explanation, for example: picture of the mentioned thing. Description may contain one or more short paragraphs depend on the 
requirement (Pardiyono, 2013). The characteristic of the description are; describe about the topic and describe about physics, quality, character or attitude about something. To analyze the data, researcher used the indicator and criteria of scoring writing descriptive text based on Jacob' theory such as organization (identification and description) (Jacob, 1988).

The researcher presents the description of the students' skill in writing the generic structure mastery of the descriptive text. For, identification is a general opening statement in the first paragraph or the first sentence that introduces the subject of the description to the audience but, the students mastered to write description, description is a series of paragraphs about the subject where each paragraph usually begins with a topic sentence.

Mean of writing generic structures in descriptive text at the class VIII that related to identification is $12.85(64 \%)$, and description is $14.14(70 \%)$. It means that a generic structure of writing descriptive text mostly mastered by the students was description. The graphic below shows the students' mastery of generic structures of descriptive text.

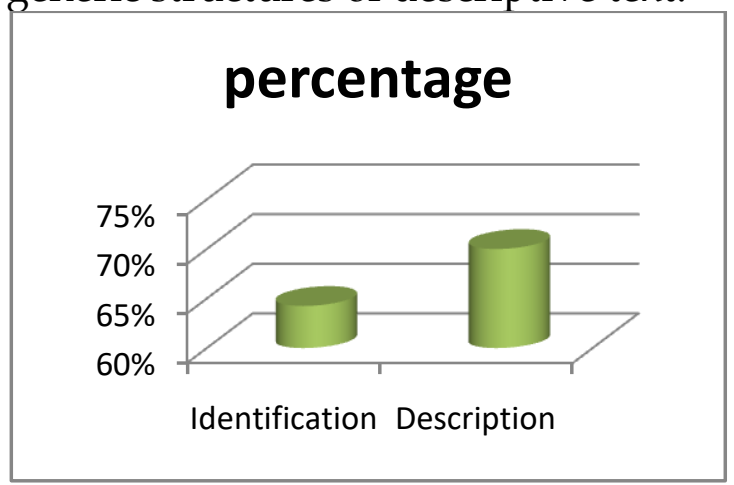

Graphic 3. Students' Mastery on Writing Descriptive Text based on Generic Structures

\section{Students' Mastery on Recount Text}

This part provides the results or finding of the research from writing test that was given to respondents at class VIII of Junior High School 2 Sintoga and Junior High School Kubang Putih.

\section{Students' Mastery of Writing Components}

The student's writing in content of the text knowledgeable; substantive; thorough development of thesis. Meanwhile, the organization of the text is well organized; logical sequencing, ideas clearly stated. Next, they have effective word/idiom choice and usage, appropriate register in vocabulary of student's writing. language use that they use is effective complex constructions, few errors of agreement, tenses, number, word order, article, pronouns, and preposition. And the last, they have demonstrates mastery of conventions few errors of spelling, punctuations, capitalization, paragraphing. The table below shows the result of the writing test that researcher gave to the students.

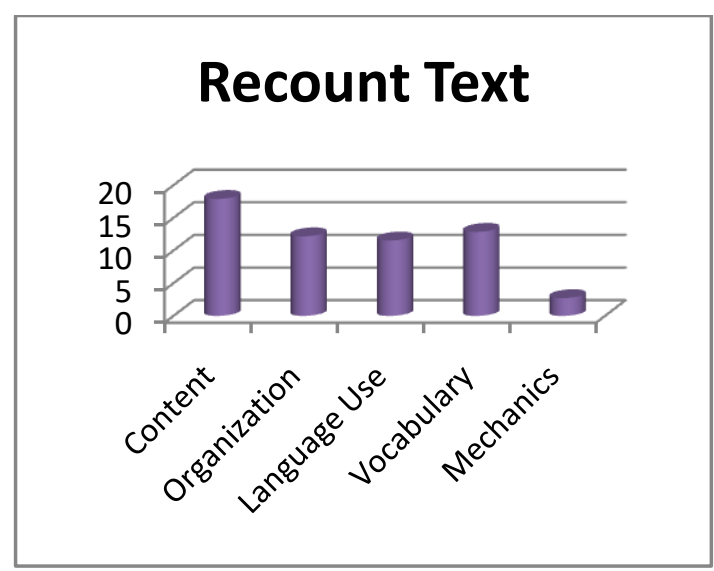

Graphic 4: Students' Mastery on Recount Writing Components 
From the table above, it can be seen that the mean of the writing test is 57.18 point. It means that the mean of students' score is below the Minimum Achievement Criteria for English lesson that is 75 point. The maximal score for each component are 26 for content, 17 for organization, 18 for vocabulary, 21 for language use and 4 for mechanics. The highest score that one of the student got is 86 point and the lowest score is 45 point.

\section{Students' Content Mastery}

Someone can be said a good writer or excellent with score 30-27 of content if they can write the content of the text knowledgeable; substantive; thorough development of thesis and relevant to assigned topic. Good average with score 26-22 if they can express the content of the text in some knowledge of subject, adequate range, limited development of thesis, mostly relevant to the topic, but lack detail. Fair to poor with score 21-17 point they can express the content of the text in limited knowledge of subject, little substance, inadequate development of topic. Very poor with score 16-13 of content if does not show knowledge of subject, non-substantive, not pertinent, or not enough to evaluate.

It was found that the mean score of content is $17.90(59.67 \%)$ In addition, the average of student's mastery in content is poor. It means that they cannot write the content of the text knowledgeable; substantive; through development of thesis and relevant to assigned topic well. Students' mastery in content divided into three scoring categories. Those are good score, fair score, and poor score. The highest score in content that students got is 26 points and the lowest score is 15 points. The graphic below shows that the students' mastery in content of writing recount text.
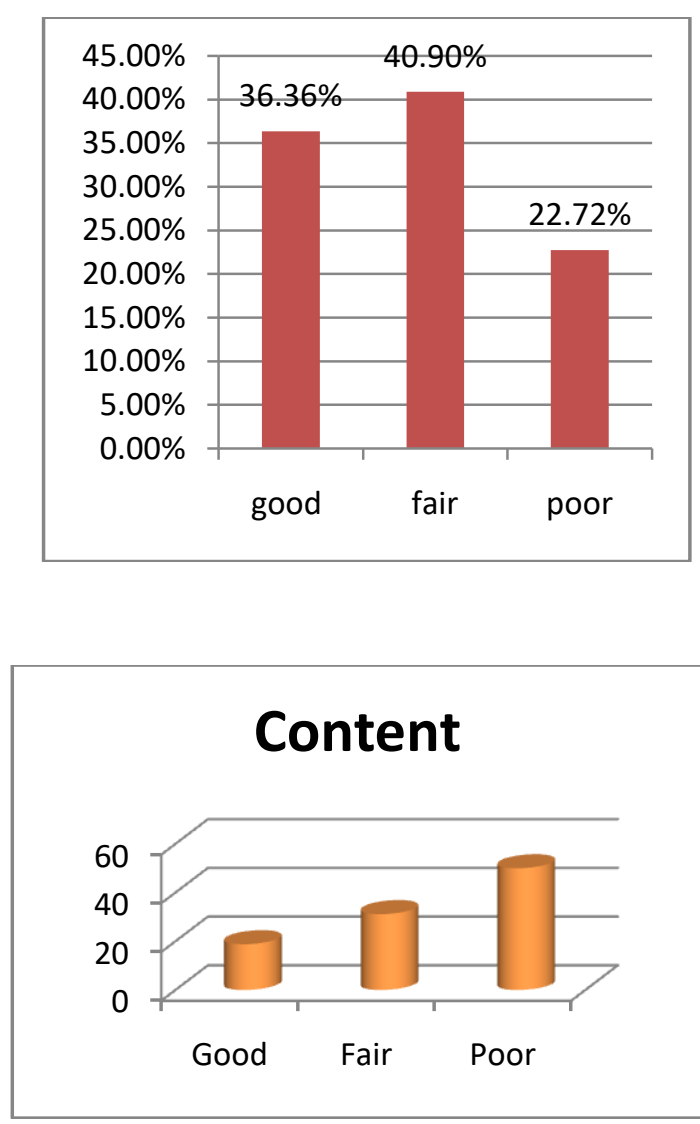

Graphic 5: Students' Mastery on Content on Recount

The graphic above tells that the percentage of the writing test at class IX in content mastery which indicated $18.18 \%$. It means that the students can write a good content, where they can construct a recount text that relevant to the topic that they have chose. Meanwhile, $31.81 \%$ got fair score. It indicates that those students have a little knowledge about the topic to build a good recount text. And the last 50\% got poor score. It means that those students did not show the knowledge about the 
topic that they chose. They cannot construct an acceptable paragraph.

\section{Students' Mastery on Organization}

Someone can be said a good writer or excellent of organization with score 20-18 if organization of the text is well organized; logical sequencing, ideas clearly stated, fluent expression, and cohesive well. Good to average of organization with score 17-14 if the organization of the text somewhat choppy, loosely organized but main ideas stand out, limited support, logical but incomplete sequencing. Fair to poor of organization are non-fluent, ideas confused or disconnect, lacks logical sequencing and development. Very poor organization with score 9-7 does not communicate, no organization, or not enough to evaluate.

It was found that the mean score of organization is $12.18(60.9 \%)$. In addition, the average of student's mastery in organization is fair. It means that organization of the text was not well organized; logical sequencing, ideas clearly stated, fluent expression and cohesive. Students' mastery in organization divided into three scoring categories. Those are good score, fair score, and poor score. The highest score in organization that students got is 17 points and the lowest score is 9 points. The chart below shows that the students' mastery in organization of writing recount text.

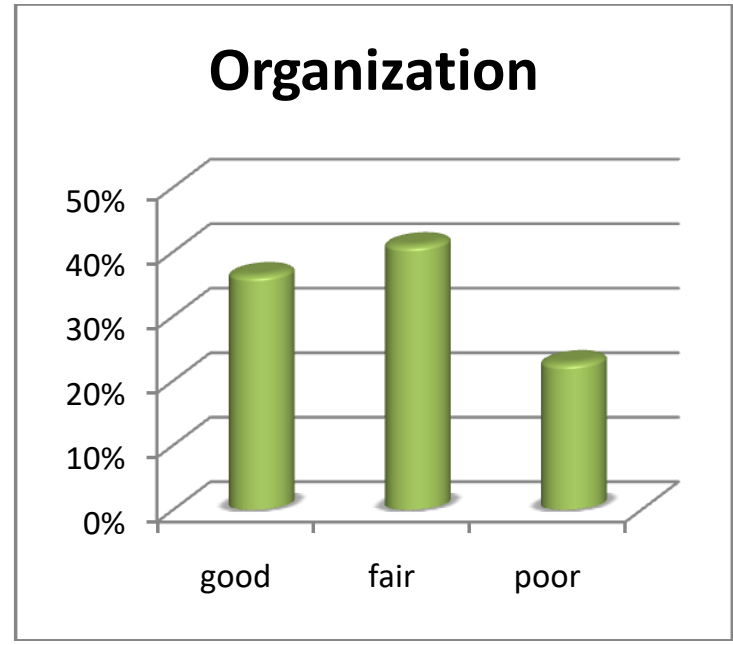

Graphic 6: Students Writing Skill

Mastery of Organization

The graphic above tells that the percentage of the writing test in organization mastery which indicates $36.36 \%$ got good score. It means that the organization of the text somewhat choppy, loosely organized but main ideas stand out, limited support, logical but incomplete sequencing. Meanwhile, $40.9 \%$ got fair score. It indicates that those students cannot express their ideas well. It made the paragraph they have written was difficult to understand by other because the ideas was confused and disconnected. And the last 22.72\% got poor score. It means that in writing the paragraph, those students cannot organize the paragraph well. Their writing did not communicate at all. The reader cannot catch the idea detail.

\section{Students' Vocabulary Mastery}

Someone can be said a good writer or excellent of vocabulary with score 2018 if they have effective word/idiom choice and usage, word form mastery, appropriate register. Good to average of vocabulary with score 17-14 are 
adequate range, occasional errors of word/idiom form, choice, usage but meaning not obscured. Fair to poor of vocabulary with score 13-10 which indicated limited range, frequent, errors of word/idiom form, choice, usage: meaning confused or obscured. Very poor of vocabulary with score 9-7 if they have essentially translation; little knowledge of English vocabulary, idioms, word form, or not enough to evaluate.

It was found that the mean score of vocabulary is $11.54(57.70 \%)$ In addition, the average of student's mastery in vocabulary is fair. Vocabulary mastery related how the students chose an effective word or idiom and it is used in the text that they wrote. Students' mastery in vocabulary divided into three scoring category. Those are good score, fair score, and poor score. The highest score in vocabulary that students got is 18 points and the lowest score is 8 points. The chart below shows that the students' mastery in vocabulary of writing recount text.

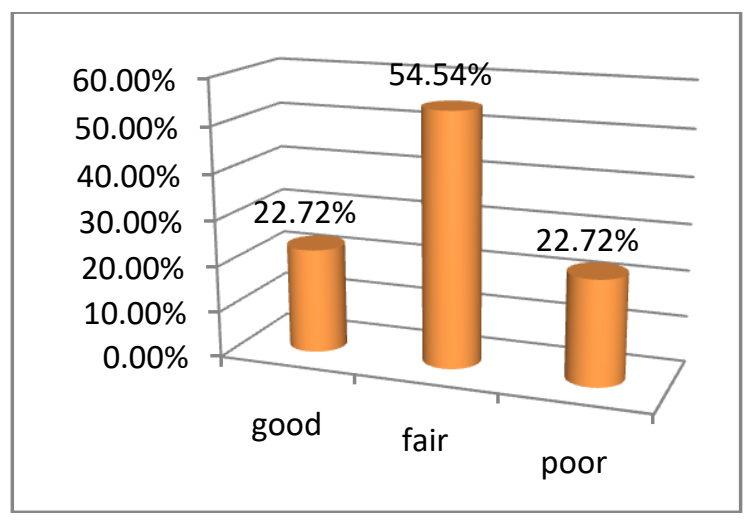

Graphic 7. Students Writing Skill Mastery of Vocabulary

The chart above tells that the percentage of the writing test at class IX in organization mastery which indicates
$22.72 \%$ got good score in vocabulary mastery. It means that those students can write the text with a good spelling, lack of mistake in the word choices and can use the word appropriately. It also means that the reader can catch the meaning that the writer wants to convey. Meanwhile, $54.54 \%$ got fair score in vocabulary mastery. It indicates those students made occasional error of words, idiom, and sometimes the reader hard to catch what the writer wants to tell. The last one is students in poor score, which include $22.72 \%$. It means in writing the paragraph, the students translated the word literally from Indonesian language to English. Students also made frequent error in word choices, and made the meaning obscured.

\section{Students' Language Use Mastery}

Someone can be said a good writer or excellent of language use with score 25-22 if they use effective complex constructions, few errors of agreement, tenses, number, word order, article, pronouns, prepositions. Good to average with score 21-18 which the text is effective but simple construction; minor problems in complex constructions; several errors of agreement; tense, number, word order/function, articles, pronouns, preposition but meaning seldom obscured. Fair to poor with score 17-11 if they write major problem in simple/complex construction; frequent error of negotiation, agreement, tense, number, word order/function, articles, pronouns, preposition, and/or fragment, run-ons, deletion; meaning confused or obscured. Very poor with score 10-5 if they write virtually no mastery of 
sentence constructions rules; dominated by errors; does not communicate or not enough to evaluate.

It was found that the mean score of language use is 12.86 (51.44\%). In addition, the average of student's mastery in language use is fair. Students' mastery in language use divided into three scoring category. Those are good score, fair score, and poor score. The highest score in language use that students got is 21 points and the lowest score is 10 points. The chart below shows that the students' mastery in language use on writing recount text.

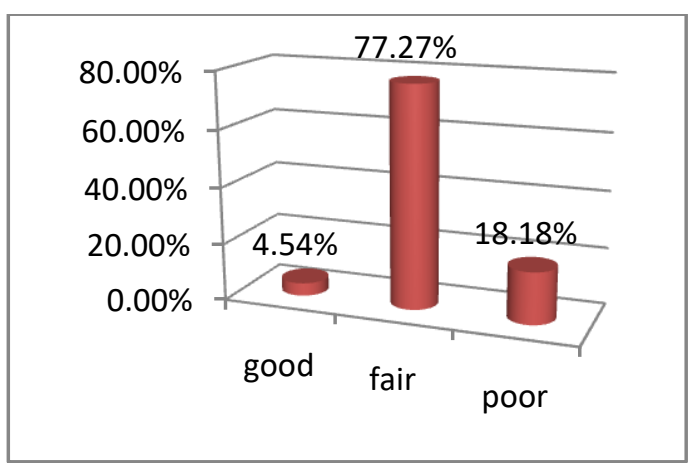

Graphic 9: Students Writing Skill Mastery of Language Use

The chart above tells that the percentage of the writing test in language use mastery which indicates $4.54 \%$ got good score. It means that the student can write the text in correct tenses, appropriate articles, pronoun, and prepositions. It also means that the students can write effective construction of the text. Meanwhile, $77.27 \%$ got fair score in language use mastery. It indicates those students made major problem in simple construction, made frequent errors of articles, pronoun, preposition, or the use of tenses. The last one is students in poor score, with
$18.18 \%$. It means that in writing the paragraph, the students did not master the sentence construction rules, dominated by error in tenses, pronoun, preposition or article.

\section{Students' Mechanics Mastery}

Mechanics is related to students' skill in writing the correct spelling, punctuations, and capitalizations. This also related to the skill of students convey the meaning to the reader. Excellent to very good with score 5 point if they demonstrates mastery of conventions few error of spelling, punctuations, capitalizations, paragraphing. Good to average with score 4 point if the text is occasional spelling, punctuation, capitalization, paragraphing, but meaning not obscured. Fair to poor with score 3 point indicates that frequent errors of spelling, punctuation, capitalization, paragraphing, poor handwriting, meaning confused or obscured. Very poor with score 2 point if there is no mastery of convention dominated by errors of spelling, punctuation, capitalization, paragraphing, handwriting illegible, or not enough to evaluate.

It was found that the mean score of mechanics is $2.72(54.40 \%)$. In addition, the average of student's mastery in mechanics is fair. Students' mastery in mechanics divided into three scoring category. Those are good score, fair score, and poor score. The highest score in mechanics that students got is 4 points and the lowest score is 2 points. The chart below shows that the students' mastery in mechanics on writing recount text. 


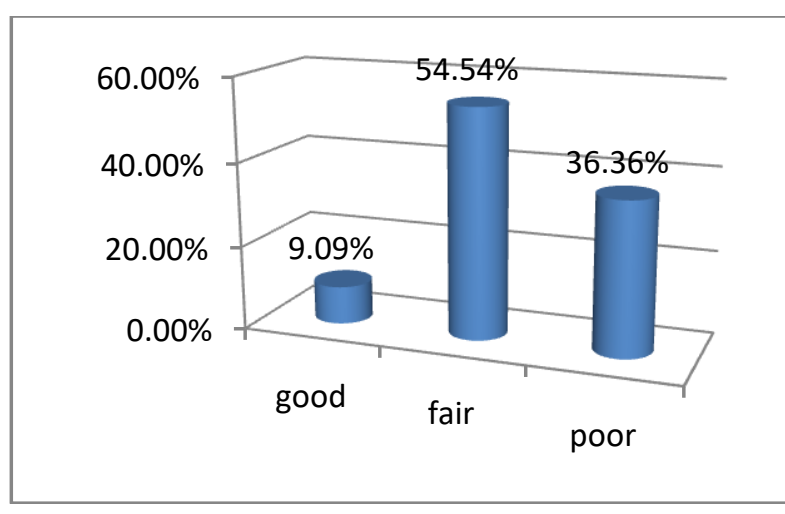

Graphic 10: Students Writing Skill Mastery of Mechanics

The chart above tells that the percentage of the writing test in mechanics mastery which indicates $9.09 \%$ got good score. It means those students can write the text with a good spelling, lack of mistake in the word choices, and can use the word appropriately. It also means the reader can catch the meaning that the writer wants to convey. Meanwhile, $54.54 \%$ got fair score in mechanics mastery. It indicates those students made occasional error of spelling, punctuations, capitalizations, paragraphing, poor handwriting, and the meaning they want to convey to the reader is confused or obscured. The last is $36.36 \%$ in poor score. It means in writing the paragraph, the students' writing dominated by error spelling, punctuation and capitalization.

\section{Students' Mastery of Generic Structure of Recount Text}

The description of the students' skill in writing generic structures of the recount text by using and criteria of scoring Department of Education WA. The students' skill in writing generic structure of recount text is divided into four stages. Those are beginning stage, developing stage, consolidating stage, and extending stage.

The student's skill in writing recount text in beginning stage is the students provide little information about setting in orientation (e.g. tells who, where, but not when), including only those events that have personal experience and some events in sequence for writing events, and the students conclude with a personal comment for writing re-orientation paragraph. Meanwhile, the student's skill in writing recount text at developing stage is the students provide sufficient information and giving simple details (who, when, where, what, why, and how) in writing orientation paragraph, including additional information about the more important events and lists all events in chronological order for writing events, and concluding with a personal evaluative comment for re-orientation paragraph.

Next, In the consolidating stage, the writer includes contextual and environmental details that impact on the way events unfold in the orientation paragraph. The writer elaborated important events for events paragraph and also including with an evaluative in summarizing comment appropriate to the form for the re-orientation paragraph. There is no students at extending stage. The chart below shows that the percentage of students writing of generic structure on recount text. 


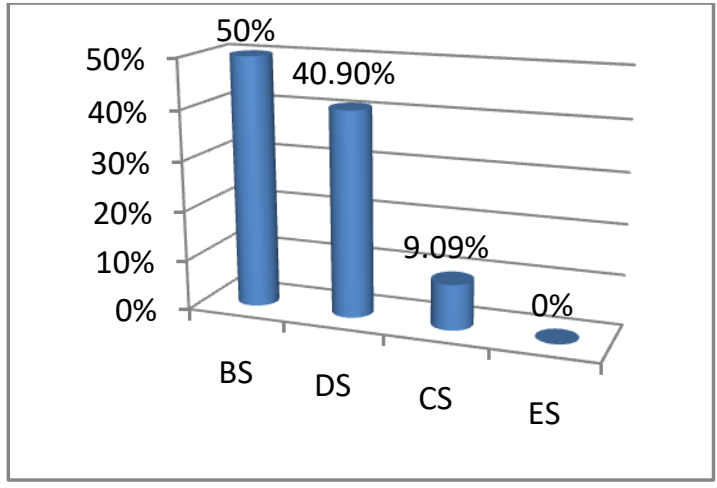

Graphic 11. Students Writing Skill Mastery of Generic Structure

Based on the chart, there were $50 \%$ at the beginning stage, $40.9 \%$ at the developing stage, $9.09 \%$ at the consolidating stage, and there was no student at the extending stage.

Based on the result analysis of students writing test and the stages above, it was found that most of them have been able to write recount text especially the generic structures of recount text. But some of them were not able to apply it well. There were some mistakes that is written by them. The mistakes have been wrote by them are in the orientation and event.

First, the orientation in writing recount text. The students should be able to write the paragraph orientation to give information that related to the questions; who, when, where, what, why, and how. And also she/he provides that includes contextual and environmental details that impact on the way events unfold. All of that tell about the people, time, place, the reason, etc. Actually, almost of them cannot do it well. The student can tell the people, time, and place. But not reason. Next, the student can tell the time and people, but not place.
Second, the events in writing recount text. The students should be able to elaborate lists events in chronological order. The students tell the experience in detail. In fact, almost of them cannot do it well. The students unchronological order in writing events, telling the events in one sentence, and cannot elaborate important events.

There are five main components of writing components should be mastered by the students. First, content of the text is knowledgeable; substantive; thorough development of thesis. Second, the organization of the text is well organized; logical sequencing, ideas clearly stated. Third, they have effective word/idiom choice and usage, appropriate register. Fourth, language use that they use is effective complex constructions, few errors of agreement, tenses, number, word order, article, pronouns, preposition. Fifth, they have demonstrates mastery of conventions few errors of spelling, punctuations, capitalization, paragraphing.

There are four stages of it. First, beginning stage that provides little information about setting or context (e.g. tells who and where, but not when), includes only those events that have personal significance, and concludes with a personal comment. Second, developing stage that gives simple details about (who, when, where, what, why, and how) in orientation, differentiating between events by including additional information about the more important events and lists all of events in chronological order, and concluding with a personal evaluative comment. Third, consolidating stage 
which provides an orientation that includes contextual and environmental details that impact on the way events unfold, elaborating important events, and concluding with an evaluative or summarizing comment appropriate to the form. Fourth, the extending stage which provides an orientation that both sets the scene and aims to interest the reader, including significant events chosen to add interest and impact, and concluding with a personal reflection or summarize the text.

Based on the finding of the research can be stated that the students' writing skill on recount text was still low. It means that the score were below the Minimum Achievement riteria for English lesson that is 75 point. The students also have some problems in mastery of mechanic. It indicated that those students made occasional error of spelling, punctuations, capitalizations, paragraphing, poor handwriting, and the meaning they want to convey to the reader is confused or obscured. This result is relevant with several researches. These were relevant studies in my research finding. Students writing skill is fair and the components of writing that haven't mastered by students were vocabulary and language use, organization, content, but the most be problematic at language use, and mechanics such as such as using punctuation, spelling and capitalization because they did not appropriately use point, coma and capitalization. (Harputra, 2014; Sefrina, 2014; Salamah, 2015).

In addition, the researcher analyzed the written text by using generic structure of recount texts. There are three generic structure of recount text: orientation, series of event, reorientation. From the finding research above the almost of half students' generic structure standing at beginning stage categorize that indicate little information about setting or context in which the events happened for orientation paragraph, including only those events that have personal significance, and concluding with a personal comment for re-orientation paragraph. Erma (2008) found that some students used the correct generic structure and some of them did not use in their writing recount text. In writing the orientation, the events, and the reorientation, most of them could not write completely. The result of the students' writing recount text was still low, she found that they are lack of vocabulary, using appropriate tenses are also causes of the students' problems. And the recount writing is new for the students and so are the teacher, it is so difficult for them to write and to teach it. Next, Azhar (2015) found that $93 \%$ of students did write the orientation, $40 \%$ with one paragraph event and 36\% with two paragraphs event, and the last $86 \%$ for paragraph re-orientation. The problems are the student difficulties to faced orientation and re-orientation.

\section{CONCLUSION \\ RECOMMENDATION}

AND

It is concluded that students' writing skill is fair and the components of writing that haven't mastered by the students. Meanwhile, the students' did not master the generic structure of 
descriptive and recount text, and they stood at beginning stage or poor of writing generic structure on recount text. They have written mistakes in orientation and events. They also have written mistakes on description on descriptive text.

Based on the result of this study, the researcher purposes some recommendations for English teacher and others who are concerned with English education. The teacher should be able to create good atmosphere while teaching writing in the classroom and also she/he should be able to find out effective techniques and strategies to teach writing. It is suggested for the English teacher could help the students to practice the use of language in written form. So, the students will be more interested in learning English especially in writing..

\section{REFERENCES}

Aji, Muhammad Y.M. (2017) Study on Teaching and Learning Writing Skill of Recount Text. Unpublished Thesis.IAIN Surakarta.

Arikunto. S. (2010). Prosedur Penelitian Pendekatan Praktis. Jakarta: Rineka Cipta

Ari, Makmuroh. 2010. Improving Students' Recount Text Mastery Through Students Text and Cooperative Learning. Surakarta. Universitas Sebelas Maret
Azhar, Syaiful. 2015. An Analysis of Generic Structure of Recount Texts (the study of fourth semester students of STAIN Salatiga in the academic year of 2012/2013). Salatiga. IAIN Salatiga

Brown, H. Douglas. (1994). Teaching by Principles: An Interactive Approach to Language Pedagogy. New Jersey: Prentice Hall Regents

Brown, H. Douglas. (2007). Langauge Asssesment: Principles and Classroom Practices. Longman

Department of Education WA (2013) .First Steps:Writing Resource Book. Western Australia

Derewianka, Beverly. 1990. Exploring How Texts Work. Australia: Primary English Teaching Association

Dadi, L. (2015). How to Write a Short Essay in English Academic Writing. Bandung: Alfabeta.

Erma. (2008). An Analysis of Generic Structure in Students Writing in Recount Text at Eight Grade (a case at year VIII students of SMP 29 Padang). (Unpublished Thesis). Padang State University

Gay, L.R. (2000). Education Research; competencies for analysis and application, Ohio: Merill Publisher Company.

Harmer, Jeremy. (2004). The Practice of English Language Teaching.4 ${ }^{\text {rd }}$ Edition.Essex: Longman . 
Hyland, Ken. 2003. Second Language Writing. New York. Cambridge University Press.

Istibsyaroh, A.L (2014). Grammatical errors on students' writing of recount text. Unpublished Thesis. UIN Jakarta.

Jacobs. L. Holly. (1981). Testing ESL Composition: A Practical Approach. London

Knapp, Peter \& Megan Watkins. (2005). Genre, Text, Grammar Technologies for Teaching and Assessing Writing. Sydney. University of South Wales

Linse, T. Caroline. 2005. Practical English Language Teaching: Young Learners. New York. McGraw-Hill ESL/ELT.

Litinin, Halira Abeni \& Babola. (2012. The Effect of Process-Genre Based Approach on the Written English Performance of Computer Science Students in a Nigerian Polytechnic. ISSN Journal. Vol 3 No 6.
Mursyid, M. (2006). English learning Handout for Grade VIII Learning Descriptive Text.

Nugraha, I.S \& Marzuki Noor. (2012). An analysis of the tenth grade student's writing ability in recount text of MAMuhammadiyah 1Metro.

Oshima, Alice \& Ann Hogue. (2006). Writing Academic English. Fourth Edition. New York: Pearson Longman

Sudijono, Anas. (2006). Pengantar Statistik Pendidikan. Jakarata: PT. Raja Grafindo Persada.

Wiegle,Sara Cushing. 2002. Assesing Writing . Cambridge: Cambridge University Press.

Yan, Guo. (2005). A Process Genre Models for Teaching Writing. English Teaching Forum. Vol 43, no 3. 